\title{
CHILDREN AS VICTIMS OF DOMESTIC VIOLENCE - DEPRIVATION OF PARENTAL RIGHTS ACCORDING TO THE FAMILY LAW ACT OF THE REPUBLIC OF NORTH MACEDONIAAND THE FAMILY LAW ACT OF KOSOVO
}

\author{
Asst. Prof. Arta Selmani-Bakiu \\ Faculty of Law, South East European University, Tetovo, North Macedonia \\ arta.selmani@seeu.edu.mk \\ MA Julinda Elezi \\ Faculty of Law, South East European University, Tetovo, North Macedonia \\ je17142@seeu.edu.mk
}

\begin{abstract}
Domestic violence is one of the most serious forms of violation of basic human freedoms and rights regardless of ethnicity, gender, religion, and status. A reflection on many international statistics shows that women are the most frequent victims of domestic violence. Based on the definition of the phenomenon of domestic violence, the forms of abuse, the manner how violence is treated, the possibility of children, men, extramarital spouses, brothers, sisters, and old people living in an extended domestic community, of also being victims is not excluded. Since domestic violence is not only a national problem but a worldwide problem, international organizations have worked towards the eradication of this phenomenon by sanctioning it in various international conventions. Also, the legal systems of many countries prohibit and sanction domestic violence by special laws obliging the state authorities to act in all situations when there are indications that there are direct or indirect violent acts in a family. In this paper, the authors present only the domestic violence against children as an evident
\end{abstract}


problem in families, but which is often unreported. The legal frameworks of the Republic of North Macedonia and Republic of Kosovo are presented in this paper with the aim to describe the material-legal and procedural-legal treatment of domestic violence by pointing out the failure of the state authorities in implementing the laws on protection and prevention of this phenomenon. The authors take the approach of only treating the legal consequences of child abuse by parents that in both legislations is deprivation of parental rights for the violent parent. They conclude that the state authorities should intensify their work in taking control measures towards all the families where there are suspicions that the parental rights are neglected, and the child is abused. Because many cases of abuse have not been detected or reported, and in both countries a special study especially on domestic violence against children does not exist, the possibility that the number for this type of child abuse is great.

Keywords: domestic violence, deprivation of parental rights, children as direct and indirect victims

\section{INTRODUCTION}

According to Selmani-Bakiu "family is one of the most important pillars of any society. Every child has the right to be cared about and to grow up in a functional and healthy family, to develop their emotional and intellectual potential, and to grow into a healthy and respected individual. The rights and obligations of a family derive from this right of the child, hence, from the right of the child to live with their parents and the obligation of the parent to ensure a decent and healthy family life for their child through responsible exercise of their parental rights" (Selmani- Bakiu, 2016, p.80).

The main principle is that the child should live with their parents. This principle is guaranteed by international conventions ("Child shall not be separated from his or her parents against their will, except when competent authorities subject to judicial review determine, in accordance with applicable law and procedures, that such separation is necessary for the best interests of the child. Such determination may be necessary in a particular case such as one involving abuse or neglect of the child by the parents, or one where the parents are living separately and a decision must be made as to the child's place of residence" Article 9, para.1, Convention on the

Rights of the Child, 1989, CRC) as well as by the Family Law of the Republic of Macedonia (Article 47, para. 1, FL) and the Family Law of Kosovo (Article 125, para. 2, FL). The parents 
are the main persons in the life of a child and they must take care of him/her, his/her life, psychophysical health, and welfare. Hence, one of the functions of the family is also the protecting function - the parents are the ones who should offer their children protection and provide life stability in the family and society. Another very important function is the emotional one. The family becomes a place of developing mutual feelings of love, solidarity, empathy, respect, as well as of the environment for realizing the cultural needs of an individual. By this, the family becomes the main factor in creating and developing the emotional, intellectual, and cultural activities and affinities of the individual (Zendeli, Selmani-Bakiu, Mickovik, Ristov, 2020, p.98). Based on all these parental obligations towards offering safety, protection, love, solidarity, maintenance, the parents are the ones who should give the main contribution in raising and educating their children. But not always the family is the safest shelter because domestic violence in some families is the main weapon for solving problems and conflicts between spouses and between the parents of the children. In these situations, the children are direct or indirect victims of domestic violence that could occur in the form of physical, psychological/emotional, economic, sexual violence/abuse. Ortiz stated that "incest or sexual abuse of children and adolescents within the family is one of the least visible forms of violence. Since crime is committed mostly by the father, stepfather, grandfather, brother, uncle or other male relative that is in a position of trust, the rights of the child are usually sacrificed in order to protect the family name and the adult who committed the crime" (Ortiz, 2016, p.44). According to the World Health Organization, violence against children including domestic violence has very serious consequences on the child's mental and physical health: resulting in death, leading to severe injuries, resulting in negative coping and health risk behaviors, leading to unintended pregnancies, contributing to a wide range of noncommunicable diseases, impacting opportunities and future generations (World Health Organization, 2020). The World Health Organization reports that "No country or community is untouched by violence. Images and accounts of violence pervade the media; it is on our streets, in our homes, schools, workplaces and institutions. Violence is a universal scourge that tears at the fabric of communities and threatens the life, health and happiness of us all" (Ibid.). It is important to point out that violence against children including domestic violence is punishable by all national laws and international documents, as a direct impact of one of the significant documents on the rights of the children - CRC which under paragraph 9 states that: "State Parties shall take all appropriate legislative, administrative, social and educational measures to protect the child from all forms of physical or mental violence, injury or abuse, neglect or negligent treatment, maltreatment or exploitation, including sexual abuse, while in 
the care of parent(s), legal guardian(s) or any other person who has the care of the child. Such protective measures should, as appropriate, include effective procedures for the establishment of social programs to provide the necessary support for the child and for those who have the care of the child, as well as for other forms of prevention and identification, reporting, referral, investigation, treatment, and follow-up of instances of child maltreatment described heretofore, and, as appropriate, for judicial involvement" (CRC, 1989). The paper is focused on the consequences following domestic violence to parental rights including the measure of deprivation of parental rights. The authors of this paper also commence from the legal framework of both countries, the Republic of North Macedonia and Kosovo, taking into consideration that the legislations of these countries are very similar in the aspect of sanctions towards violent parents as well as the proceedings of deprivation of parental rights.

\section{Domestic violence against children in the Republic of North Macedonia and the legal framework regarding protection from domestic violence}

Selmani -Bakiu indicates that "children can be victimized directly or indirectly. The following are considered as forms of domestic violence: physical and sexual violence, psychological abuse and pressure, negligence in caretaking, exploitation, forcing children to beg, insults, underestimation, threats, cause of the feeling of fear, limitation of the freedom of movement, as well as other actions that impinge the child's dignity and personality" (SelmaniBakiu, 2015, p.167). As stated by Savovska, Galevska \& Velkovska, "physical violence is more emphasized; even though the intensity of the actions can be low, it can cause long-life consequences in children. Psychological violence is less visible but can cause incurable consequences in the child's psychosocial development (Savovska, Galevska \& Velkovska, cited by Selmani-Bakiu, 2015, p.168). Also, in the opinion of Savovska, Galevska \& Velkovska "emotional violence can also be indirect when the victim is present during the physical or psychological maltreatment of another family member. In these cases, the child is considered a secondary victim. Children that are raised in families where violence prevails are victims, regardless of whether they have directly been affected or have witnessed violence exercised against any other member of their family. It is more than evident that violent behavior between parents affects their children's development and reflects negative consequences in their lives, such as anxiety, depression, difficulties at school, aggressiveness, theft, drug abuse, lack of self-confidence, etc.”. (Ibid.). According to the authors G. Jaffe, K. D. Lemon, \& E. Poisson, children exposed to domestic violence may exhibit a wide variety of symptoms, such as 
aggressive and non-compliant behavior; emotional and internalizing problems; effects on social and academic development; posttraumatic stress disorder; subtle symptoms (G. Jaffe, et al, 2003, p.23-24). According to a considerable number of authors the most frequent child abuse is representing them in the capacity of the indirect victims, thus according to Kashani, Carlson, Ortiz by the transmission of abuse pattern, children become shadow victims, parents making them responsible for family problems. Thus, we are witnessing either externalization mechanisms (child runs away from home, is angry and aggressive, particularly boys) or internalization mechanisms (child becomes anxious and depressed, blames self, develops suicidal thoughts) (Kashani, 1998, as cited in Carlson, 1990, cited in Ortiz, 2016, p.55).

In Republic of North Macedonia, regarding the protection of the children we can refer to the national documents like the Constitution of RNM (1992) Law on Prevention, Combating and Protection from Domestic Violence (2014) Family Law Act (1992); Law on Child Protection (2013); Law on Social Protection (2009); Criminal Code (1996) and National strategies and Action plan for the protection of children from violence (2020-2025). Protection of children against domestic violence is one of the basic rights of every child. Unfortunately, domestic violence remains a serious problem for millions of children in the entire world with long-term consequences in their development, health, and welfare. When we speak about violence against children it is very difficult to determine the real level of the problem, mainly due to the insufficient reporting of cases of children as victims. However, research conducted throughout the world and in our country shows that many children suffer from violence in silence. Violence occurs at home and in the community and often remains unregistered by the institutions for the protection of children (Ministry for Labor and Social Policy, 2020). In the study of 2017 in the Republic of Macedonia conducted by UNICEF, it was concluded that "4 out of 5 children in the country face violence from their parents. Even though more than $2 / 3$ of parents are aware of the negative effects of violent methods for disciplining children, children are too often exposed to at least one form of violence within their homes, from psychological aggression to minor or severe physical punishment" (UNICEF, 2017). Also in this sense, it is worth mentioning the statement of the President of the country Stevo Pendarovski at the conference "Scaling up action to end violence against children in the Western Balkans" who mentioned that based on latest studies 8 out of 10 parents use physical and psychological violence against their children (Denesen vesnik, 2019). These numbers show that despite many activities of the state authorities, international organizations, and non-governmental organizations, domestic violence against children remains a form of family "education". 


\subsection{Deprivation of parental rights as a result of domestic violence pursuant to the legislation of the Republic of North Macedonia}

There are situations when parents are not led by the principle of respecting the highest interest of the child, and thus they neglect their parental obligations or misuse the property interests of the child. Hence, all the actions of the parents that are in contradiction to the interest of the children are sanctioned by national laws of the country and these provisions order the limitation or deprivation of parental rights.

In case of neglecting parental obligations towards their children or towards only one child regarding care and education, and in cases when there is a serious risk for proper development of the children, the measure of limitation of exercising the parental rights can be imposed (Zendeli, Selmani-Bakiu, Mickovik, Ristov, 2020, p.249).

The other most severe measure imposed on the parent who constantly and brutally misuses the parental rights and obligations is deprivation of the parental rights. According to the J.Ross "The conflicting interests that can arise among parents, children and the state are particularly pronounced when the state seeks to terminate parental rights. The resulting tensions have long been aggravated by the inability of the child welfare system to find the proper balance between two competing imperatives. The first requires the state to protect children who are the victims of serious abuse or neglect and who, it is widely understood, may suffer repeated trauma, and even death, if the state fails to intervene appropriately. The second imperative is to minimize the psychological and social trauma that children often suffer when the state intervenes to remove them from the families that have failed to meet their basic needs" (J. Ross, 2004).

The measure of deprivation of parental rights is a repressive measure for the protection of the child's interests. This measure is imposed after all the suppositions anticipated by law are met that result in negative effects to the child that could eventually damage the child if he/she would continue to live with his/her parents. The main purpose of this measure is the protection of a child's interests (Zendeli, Selmani-Bakiu, Mickovik, Ristov,2020, p.251). Based on FL, the actions considered as misuse of the parental rights and obligations are exercising physical or psychological violence against the child; sexual exploitation of children; forcing a child to do work not consistent with his/her age; permission to use alcohol, drugs or other psychotropic substances; forcing and exploiting a child to beg; leads the child to socially unacceptable behaviors; abandoning a child for more than 3 months; in any other harsh manner violates the rights of the child (Article 90, FL). In such situations, the state authorities (Ministry of Labor and Social Policy, Ministry of Internal Affairs, Ministry of Health, Ministry of 
Education and Science, Ministry of Justice, units of local self -government, institutions that perform activity in the field of social protection, child protection, internal affairs, health, employment and education), including the Center for Social Work (CSW), and the public prosecution office, are obliged to initiate a proceeding for deprivation of the parental rights in all situations when there are indications and information about such misuses of the parental rights (Article 91, FL). If the parent who has neglected or illtreated the child, does not act in accordance with the CSW to improve his attitude towards the child and non-recurrence of violence in this case and continues to abuse the child or in other ways to misuse the exercise of the parental rights, CSW is obliged to immediately to take the child from the parent and to initiate the proceedings of deprivation of parental rights at the competent court. Except for these proceedings, the CSW is obliged to provide adequate care for the minor child and to undertake measures for the protection of his/her rights and interests until a final court decision on deprivation of parental rights. The CSW can also undertake these measures until the final court decision of deprivation of parental rights. Also, the CSW is obliged to initiate proceedings against the parent of the minor child for the committed criminal offense (Article 91 para.6, FL). The court procedure for deprivation of parental rights is non-contentious, and in detail is regulated by provisions of the Law on the non-contentious procedure (Articles 106-111). According to the Law on the non-contentious procedure, in the proceedings for deprivation of parental rights the court verifies if there are reasons of depriving the parent of the parental right or of having the position of the custodian, to return the parental rights when the reasons that caused the deprivation of parental rights to cease to exist (see also Article 92, FL).

\section{Domestic violence against children in Kosovo}

The information from the state institutions as well as from national and international organizations regarding the protection of children confirm that violence against children (physical or psychological) continues to be widespread in Kosovo (Kosovo 2.0, 2019). It should be pointed out that children, both girls, and boys are often victims of domestic violence. Except for the forms of domestic violence such as (physical, psychological, sexual, economic), negligence of children is also a form of violence exercised in the family that in many cases is not perceived or recognized as such by many parents and professionals. It is often expected that negligence is identified as a form of exercising violence in poor families, of very hard economic conditions, with uneducated parents, or that belong to a certain ethnic minority. Nevertheless, negligence can occur also among children living in rich families, of very good 
economic conditions, with educated parents, etc. Therefore, even if violence is not exercised directly on children, being present (or as it is qualified in the Istanbul Convention "witnessing violence") in an incident of violence, proved to have great influence and often leave incorrigible consequences in the lives of children. Hence the measures undertaken for the protection and treatment of children who live in a family where violence was exercised, should address the situation when they directly experienced a form of domestic violence, and the situation when children have witnessed an incident of violence. It should not be forgotten how big an influence has violence exercised on the other family members on the psychology and development of the child. Regarding the situation and the violence that children experience in the family in Kosovo, the data of a survey of the Kosovo Women's Network indicate that $32.6 \%$ citizens agree that "the child should sometimes be punished by slapping" that suggests that the slapping perhaps exists is $1 / 3$ of the families as a form of discipline (Ministry of Justice, 2016). As it is stated in the Declaration of the Rights of the Child, "the child, by reason of his physical and mental immaturity, needs special safeguards and care, including appropriate legal protection, before as well as after birth". In all countries in the world, some children live in exceptionally difficult conditions, and that such children need special consideration (CRC, 1989).

\subsection{Legal protection of children against domestic violence according to the positive legislation of Kosovo}

Based on the Law on Protection Against Domestic Violence (LPADV), domestic family signifies one or more offenses or intentional omissions that a person does to another person with whom he is or used to be in a family relationship (Article 1.2, LPADV, 2010). The LPADV aims "to prevent domestic violence, in all its forms, through appropriate legal measures, of the family members that are victims of the domestic violence, by paying special attention to the children, elders, and disabled persons" (Article 1, LPADV). "The municipal court that has the jurisdiction at the municipality where the applicant is temporarily or permanently residing or staying shall be competent to issue protection measures. Every municipal court shall have the authority to review the request for protection order or emergency protection order and for issuing the order. Protection measures shall be issued with the purpose of preventing domestic violence, to protect a person who is exposed to violence, by removing the circumstances which impact or may impact in committing other acts. The competent municipal court, with a protection order or emergency protection order, may impose one or more protection measures. The competent body for the execution of protection measures shall 
be the Kosovo Police" (Article 3, LPADV). According to the Article 4 of LPADV, "another protection measure is psychosocial treatment, which may be issued to a perpetrator of domestic violence in combination with any other preventing measure to elude violent behaviors of the perpetrator or if there is a risk to repeat the domestic violence. Ministry for Labor and Social Welfare in cooperation with the Ministry for Health and relevant institutions prepares and proposes for approval to the Government the issuance of a sub-legal act with which the way and location of the implementation of psychosocial treatment are determined" (Article 4, LPADV).

The LPADV defines a range of legal measures that aspire to protect the victims of domestic violence. It defines the domestic family and family relationships; it explains which protection measures and orders exist and the procedure that should be followed in order to provide them. The persons victims of domestic violence enjoy the right to protection orders, urgent protection orders and urgent temporary protection orders. The protection orders include the prohibition of approaching the domestic violence victim by the perpetrator of domestic violence, removal of perpetrator from living premises, accompanying the victim of domestic violence during the collection of personal items, and deprivation of parental rights for the violent parent. Domestic violence is not limited only to physical maltreatment and the victim can suffer mental and emotional traumas. Domestic violence occurs in the family context and the negative consequences usually affect children, even if they do not witness violence. Children who are victims of domestic violence are more in danger of developing serious emotional problems, behavior, and future development (OSCE, 2018).

Also, the Family Law Act of the Republic of Kosovo expect that each child enjoys the undeniable right to life (Article 125, FL). Protection of the life of the child should be the main obligation for every person, institution, or other body. The child's right to survival and development, which means the child's right to physical, mental, emotional, educational, health, social development, and well-being, must be protected to the maximum extent possible by any person, institution, or any other body (Article 4, Chapter 2, Law on Child Protection, 2019).

The more we learn about the consequences of violence on children, the clearer the measures that need to be addressed. Both short-term and long-term exposure to violence during childhood has extremely negative consequences for both mental and emotional health. Evidence suggests that the entire society can be harmed if a child suffers in this form (Islami, 2016). Respectively, this problem should be considered as an economic and social problem but also as a moral character. As mentioned above, violence against children comes in many forms; physical, psychological, and sexual. The consequences of experiencing childhood violence are 
of many forms. Determining the link between the onset of violence and the effect is complicated by other factors. For example, if we take poverty and childhood violence, although it is clear that there is a connection between the two, the exact nature remains unclear (Ibid.) Being born in poverty increases the risk of childhood violence which increases the chances of living in poverty even in adulthood, so separating the cause from the effect is a challenge. Furthermore, physical violence can cause psychological as well as physical harm. Also, the effects of psychological violence can manifest physically. Studies show that when children suffer from some form of violence, they are also more likely to suffer from other forms of violence. This is known as "poly-victimization". The negative consequences of violence accumulate, which means that 'poly-victimization' has even more devastating consequences. However, it is important to remember that the link between the origin of violence and its consequences does not mean that it is inevitable. The reaction of persons to violence is unique. Although childhood violence has consequences for the future, recovery is possible. (Islami, 2016).

\subsection{Deprivation of parental rights as a result of domestic violence}

According to the Family Law of the Republic of Kosovo, "parental responsibility is related to the right and obligation of parental care. Parental responsibility includes rights and obligations, aiming to ensure the emotional, social, and material welfare of the child, by looking after the child, preserving personal relations, providing proper growth, education, vocational training, legal representation, and administration of property. By applying these principles parents shall consider the skills, inclinations, and desires of their children" (Article 128, FL). Parents who abuse the exercise of parental rights or seriously neglect the exercise of parental obligations are deprived of custody. Parents may be deprived of custody of all their children or, if special circumstances require so, only from the custody of one child. The competent court decides to deprive the parents of parental custody in an extra contentious procedure, after hearing the opinion of the Custodian body and investigating all relevant circumstances of the individual case (Article 149, FL). Parents do not own their children; children are beings with rights. These rights must be respected everywhere, even at home. Everyone in a family has equal rights to protection from violence, regardless of how young or old he/she is. Just like adults in a family who should not hit each other, adults should not hit children either.

According to the Civil Code of the Republic of Kosovo "the Custodian body exercises general and continuous supervision of the exercise of parental rights and obligations. If the 
Custodian body learns about the existing danger to the child because of an abuse of parental rights or any danger to the child by serious neglect of parental obligations, it is obliged to urgently undertake measures for the protection of the child's personality, rights, and interests" (Articles 1273-1274, Civil Code of the Republic of Kosovo, 2019, CC). Furthermore "a child shall not be removed from the care of her/his parent/s or legal custodian without their permission or an order of the court. Exceptionally, where Custodian body has reasonable grounds to believe that there is an immediate serious risk to the health, safety, or welfare of a child, Custodian body may enter any premises and remove the child to a safe place where he/she will be taken care of, for a period not exceeding 72 hours. Before the expiry of 72 hours, the Custodian body should bring the case to the attention of the competent court, which shall decide on the child's custody. If circumstances require, the court may make an assessment order for a period of up to 21 days to allow further investigations and assessments to be made, by which time the matter must be brought to the court for further attention" (Article 1275, CC). "Parents that abuse exercise of parental rights or seriously neglect exercise of parental obligations are deprived of the parental right. Parents may be deprived of parental rights for all their children or, if special circumstances require so, they are deprived only from parental care of one child. The decision to deprive parents of parental care is taken by a competent court in an extra contentious procedure, after hearing the opinion of the Custodian Body and investigating all relevant circumstances of the individual case" (Article 1276, CC). Decision on deprivation of parental care may be initiated by the other parent, Custodian body, or Court. "The Custodian body is obliged to initiate the procedure for deprivation of parental care if it in any way learns about the existence of reasons provided" (Article 1277, CC). When talking about the child, we must first consider the development of the child. The measures taken by society must be adapted to this development. Being human beings not fully mature physically and emotionally, children cannot enjoy all the rights that belong to them, without the help of adults and the increased care of the state. These facts give the rights of the child another dimension and specificity related to human rights (Lleshi, Sylhasi, 2017, p.13-14).

\section{CONCLUSION}

Domestic violence is one of the most severe forms of violation of fundamental human rights and freedoms and is an obstacle to the functioning of a healthy family by unbalancing in this regard the material, emotional and social care among family members. The paper addresses 
domestic violence against children and the consequences it brings in the deprivation of parental rights in situations where this violent act is reported to the competent authorities. However, it is crucial that the children in the Republic of North Macedonia and Kosovo report domestic violence against them. There is no accurate empirical data on the number of child victims of domestic violence and official information on the number of court cases for the deprivation of parental rights due to domestic violence, which affects the continuous increase of the number of child victims of domestic violence and the fear of children reporting it. This points out the fact that domestic violence against children is present in our families. The authors during their research also concluded that both countries have a well-developed legal framework regarding the material-legal and procedural-legal dealing with domestic violence, but the problem lies in the implementation of these legal provisions. The problem of domestic violence against children is not evident only in RNM and Kosovo but from the research conducted in this regard, it can be concluded that it is an unresolved issue on a global level. Despite the seriousness of the problem, many countries around the world fail to provide an effective system for preventing and sanctioning domestic violence. The failure of countries to provide effective and timely intervention is a crucial element in the spreading of domestic violence and the grave consequences it causes. The inactivity of countries is most often manifested through inefficient police protection, inadequate legal solutions, inefficient court proceedings, poor health care, and lack of assistance and economic support for victims of domestic violence (Zendeli, Selmani-Bakiu, Mickovik, Ristov, 2020, p.89). The general conclusion is that state authorities should coordinate with each other and urgently need to establish mechanisms to closely investigate cases of domestic violence against children, in order to identify victims of violence on time. There is a significant number of non-governmental organizations in the Republic of North Macedonia as well as in Kosovo which provides assistance to victims of domestic violence as well as support and assistance in reporting it. It is worth mentioning the Legal Clinic "Pro Bona" within the Faculty of Law at the Southeast European University, which among other things offers free legal aid, legal advice, and legal support to victims of domestic violence with special emphasis on children. It is a fact that based on the reported cases, which are very few, the state authorities are not trusted.

Therefore, children should be offered educational programs in schools, educational activities by NGOs and Legal Clinics, with the sole purpose of distinguishing which actions are considered domestic violence, where they should report the violent action by their parents, provided in this regard with psycho-social support, legal assistance in reporting abuse and 
maltreatment by their parents as well as maintaining privacy. Domestic violence should not continue to be considered as a private or family problem, but as a public and social problem, because negligence and domestic violence create traumatic children with long-term consequences on their mental and physical health. A progressive society is a society that has healthy families and children, so it should be invested in the psychosocial welfare of the children. 


\section{REFERENCES}

1. G.Jaffe, P., K. D. Lemon,N., E. Poisson,S. (2003). Child Custody and Domestic Violence: A Call for Safety and Accountability. SAGE Publications, Inc.

2. J. Ross,C., A Delicate Task: Balancing the Rights of Children and Mothers in Parental Termination Proceedings (2004), George Washington University Law School, Gw Law Faculty publications \& other works. https://core.ac.uk/download/pdf/232645506.pdf

3. Ortiz, M. (2016). Domestic Violence: Prevalence, Risk Factors and Perspectives. Nova Science Publishers, Inc.

4. Savovska, M., Galevska, Marija.,Velkovska, S. (2008). Водич за постапување на професионалните структури при заштита од семејно насилство.Здружение на граѓани и акција Здруженска Скопје \& Здружение за еманципација, солидарност и еднаквост на жените на PM, ECE. http://zdruzenska.org.mk/ Retrieved 2021-0301.

5. Selmani-Bakiu, A. (2016). Deprivation of the parental rights according to the Macedonian legislation. Annual of the institute of sociological, political and juridical research, Volume. XL, no.2. Institute of sociological, political and juridical research, St.Cyril and Methodius University, Skopje, Republic of Macedonia. 79-90.

6. Selmani-Bakiu,A. (2015).Domestic Violence against children - negation of fundamental rights. SEEU REVIEW, Special Edition, Magna Carta $800^{\text {th. }}$ De Gruyter, 166-174.

7. Zendeli,E., Selmani-Bakiu,A., Mickovik, D., Ristov,A. (2020). E drejta familjare. Tetovo.Arberia Design.

8. Constitution of RM. (Official Gazette of the R.M, No.52/92). https://sobranie.mk/ustav-na-rm.nspx

9. Civil Code of the Republic of Kosovo. (2019). https://md.rksgov.net/desk/inc/media/89AFEE64-B2C2-4B74-B15C-CCE8C3EC76E7.pdf

10. Criminal Code. (Official Gazette of the R.M, No:37/1996). http://www.slvesnik.com.mk/

11. Family Law Act of RM (Consolidate Version, 2015). http://www.slvesnik.com.mk/

12. Law No .2004/32 Family Law of Kosovo. (2006). https://gzk.rksgov.net/ActDetail.aspx?ActID $=2410$

13. Law No.03/L -182 on Protection Against Domestic Violence. (2010). Official Gazette of the Republic of Kosova. https://gzk.rksgov.net/ActDocumentDetail.aspx?ActID=2691

14. Law No.06/L-084 on Child Protection. (2019). Official Gazette of the Republic of Kosova. https://gzk.rks-gov.net/ActDetail.aspx?ActID=20844

15. Law on Child Protection. (Consolidate Version, 2021). https://www.mtsp.gov.mk/

16. Law on Contentious Procedure. (Official Gazette of the R.M, No. 9/2008). http://www.slvesnik.com.mk/

17. Law on Prevention, Combating and Protection from Domestic Violence. (Official Gazette of the Republic of Macedonia, no.138/2014) https://www.mtsp.gov.mk/

18. Law on Social Protection. (Official Gazette of the Republic of Macedonia, No. 79/2009) https://www.mtsp.gov.mk/

19. UN Convention on the Rights of the Child. (1989). https://www.ohchr.org/en/professionalinterest/pages/crc.aspx

20. Denesen Vesnik, Насилство врз деца: И денес во Македонија 8 од 10 родители мислат дека ќотекот излегол од рајот. (2019). https://denesen.mk/nasilstvo-vrz-decai-denes-vo-makedonija-8-od-10-roditeli-mislat-deka-kjotekot-izlegol-od-rajot/ Retrieved 2021-03-25 
21. Islami, K. Pasojat e dhunës ndaj femijëve (Review from Child Hub). Child Protection Hub. (2016). https://childhub.org/sq/online-biblioteka-o-djecijoj-zastiti/pasojat-edhunes-ndaj-femijeve-rishikim-nga-child-hub Retrieved 2021-03-02

22. Kosovo 2.0. (2019). https://kosovotwopointzero.com/disiplinimi-i-femijeve-mbetetpeng-i-dhunes/ Retrieved 2021-02-12

23. Lleshi, K., Sylhasi, V. (2017). Fëmijët tanë-Udhëzues praktik për prindër dhe mësimdhënës.Qendra për $\operatorname{arsim}$ e Kosovës. http://kec-ks.org/wpcontent/uploads/2020/08/femijet_tane__udhezues_praktik_per_prinder_dhe mesimdhenes_- 05-1.pdf Retrieved 2021-02-18

24. Ministry for Labour and Social Policy of Republic of North Macedonia, (2020). Секое дете има право на безбедно и среќно детство. National strategies and Action plan for the protection of children from violence. https://mtsp.gov.mk/januari-2020ns_article-sekoe-dete-ima-pravo-na-bezbedno-i-srekjno-detstvo-vladata-usvoinacionalna-strategija-i-akciski-pla.nspx Retrieved 2021-02-25

25. Nisma globale për t'i dhënë fund ndëshkimit trupor të fëmijëve. Save the Children, Sweden. (2009). https://endcorporalpunishment.org/wp-content/uploads/faqs/FAQSQ-child-friendly-updated-2019.pdf Retrieved 2021-03-02 Retrieved 2021-01-10

26. OSCE, Kosovo. (2018). Raportimi për dhunen në familje. https://www.osce.org/files/f/documents/1/7/404351.pdf Retrieved 2021-03-25

27. Strategjia kombëtare e Republikës së Kosovës për mbrojtje nga dhuna në familje dhe plani i veprimit 2016-2020. Ministry of Justice of Kosovo, (2016) http://www.kryeministri-

ks.net/repository/docs/STRATEGJIA_KOMB\%C3\%8BTARE_E_REPUBLIK\%C3\% 8BS_S\%C3\%8B_KOSOV\%C3\%8BS_P\%C3\%8BR_MBROJTJE_NGA_DHUNA_N \%C3\%8B_FAMILJE.pdf Retrieved 2021-01-20

28. UNICEF, Republic of North Macedonia, Report, Survey on Parents' \& Caregivers' Knowledge, Attitudes, Practices re. violence against children (2017).https://www.unicef.org/northmacedonia/media/4236/file/MK_KAPonVAC_R eport_ENG.pdf Retrieved 2021-03-20

29. World Health Organization, (2020).Violence Against Children. https://www.who.int/news-room/fact-sheets/detail/violence-against-children Retrieved 2021-03-20

30. World report on violence and health: summary. World Health Organization Geneva (2002).https://www.who.int/violence_injury_prevention/violence/world_report/en/su mmary en.pdf Retrieved 2021-02-15 